\title{
Asthma and the risk of lung cancer: a meta-analysis
}

Research Paper

\author{
Yan-Liang Qu ${ }^{1, *}{ }^{*}$ Jun Liu ${ }^{2,}{ }^{*}$, Li-Xin Zhang ${ }^{1}$, Chun-Min Wu ${ }^{1}$, Ai-Jie Chu ${ }^{1}$, Bao-Lei Wen ${ }^{1}$, \\ Chao Ma ${ }^{1}$, Xu-yan Yan ${ }^{1}$, Xin Zhang ${ }^{1}$, De-Ming Wang ${ }^{1}$, Xin Lv ${ }^{2}$, Shu-Jian Hou ${ }^{3}$ \\ ${ }^{1}$ Department of Anesthesiology, Hospital of PLA, Qingdao 266071, Shandong, China \\ ${ }^{2}$ Department of Anesthesiology, Shanghai Pulmonary Hospital, Tongji University School of Medicine, Shanghai, China \\ ${ }^{3}$ Department of Hand Surgery, Hospital of PLA, Qingdao 266071, Shandong, China \\ *These authors contributed equally to this work \\ Correspondence to: Xin Lv, email: xinlvg@126.com \\ Shu-Jian Hou, email: houshujian401@163.com
}

Keywords: asthma, lung cancer, association, meta-analysis

Received: October 11, 2016

Accepted: November 18, 2016

Published: January 11, 2017

\section{ABSTRACT}

Some studies found that there was a significant association between asthma and the risk of lung cancer. However, the results are inconclusive. Therefore, we performed a meta-analysis. We searched the electronic databases for all relevant articles. Odds ratio (OR) with $95 \%$ confidence interval (CI) were used to calculate the strength of the association between asthma and lung cancer risk. Asthma was significantly associated with the increased risk of lung cancer $(O R=1.44 ; 95 \%$ CI 1.31-1.59; $\left.P<0.00001 ; I^{2}=83 \%\right)$. Additionally, asthma patients without smoking also had the increased lung cancer risk. In the subgroup analysis of race and gender, Caucasians, Asians, male, and female patients with asthma showed the increased risk of lung cancer. However, asthma was not significantly associated with lung adenocarcinoma risk. In the stratified analysis by asthma definition, significant associations were found between asthma and lung cancer in self-reported subgroup, questionnaire subgroup, and register databases subgroup. However, no significant association was observed in physician-diagnosed asthma subgroup. In conclusion, this meta-analysis suggested that asthma might be significantly associated with lung cancer risk.

\section{INTRODUCTION}

Lung cancer is one of the most common malignant tumors affecting millions of people around the world. It is acknowledged that smoking is the most important risk factor of lung cancer [1]. Sun et al. suggested that approximately $25 \%$ of lung cancer cases worldwide are not attributable to tobacco use [2]. This fact indicated that other factors might contribute to susceptibility to lung cancer.

Asthma is one of the most common diseases of childhood, with an estimated global prevalence of $10 \%$ among children aged 6-7 [3]. It is a condition characterized by chronic inflammation of the lungs, presenting with airway hyper-reactivity, excessive mucous formation, and respiratory obstruction. The chronic inflammation had an important role in the cancer development [4]. Thus, the chronic inflammation in conditions such as asthma might lead to lung cancer development. Some studies found that there was a significant association between asthma and the risk of lung cancer. However, the results are inconclusive [5-22]. Therefore, we performed a meta-analysis to determine the association between asthma and lung cancer risk.

\section{RESULTS}

Characteristics of eligible studies

The detailed literature search strategy was showed in Figure 1. A total of 884 potential studies were identified by preliminary searching. After carefully review, 18 studies were included in this meta-analysis [5-22]. Four studies reported two independent studies. Thus, 22 studies with 16375202 subjects were included. Table 1 presents the main characteristics of these studies, such as first author's name, year of publication, ethnicity, gender, age, asthma definition, lung cancer definition, duration of 
Table 1: Characteristics of the included studies

\begin{tabular}{|c|c|c|c|c|c|c|c|c|c|c|}
\hline $\begin{array}{l}\text { First } \\
\text { author }\end{array}$ & Year & Race & Gender & Age (y) & Definition of asthma & $\begin{array}{l}\text { Definition of } \\
\text { lung cancer }\end{array}$ & $\begin{array}{l}\text { Follow-up } \\
\text { years }\end{array}$ & $\begin{array}{l}\text { Samle } \\
\text { size }\end{array}$ & Covariants & NOS \\
\hline Alderson & 1974 & Mixed & Mixed & $25-59$ & Self-reported & Obtain from register databases & 21 & 1892 & No & 7 \\
\hline Reynolds 1 & 1987 & Mixed & Male & NA & Self-reported & Obtain from register databases & 18 & 3117 & Age, smoking & 9 \\
\hline Reynolds 2 & 1987 & Mixed & Female & NA & Self-reported & Obtain from register databases & 18 & 3708 & Age, smoking & 9 \\
\hline Mills & 1992 & Caucasian & Mixed & NA & Questionnaire & $\begin{array}{l}\text { Mailed questionnaires and tumor } \\
\text { registries }\end{array}$ & 6 & 34198 & $\begin{array}{l}\text { Age, sex, smoking history, } \\
\text { and time since last physician } \\
\text { contact }\end{array}$ & 9 \\
\hline Vesterinen & 1993 & Caucasian & Mixed & NA & Obtain from register databases & Obtain from register databases & 7 & 35126 & No & 7 \\
\hline Eriksson & 1995 & Caucasian & Mixed & $16-79$ & Physician-diagnosed & Obtain from register databases & 14 & 6593 & No & 7 \\
\hline Huovinen & 1997 & Caucasian & Male & $>18$ & Self-reported & Obtain from register databases & 16 & 14654 & $\begin{array}{l}\text { Age, smoking, social class, } \\
\text { pets, dogs, chronic bronchitis, } \\
\text { dyspnoea, hay fever }\end{array}$ & 9 \\
\hline Boffetta 1 & 2002 & Caucasian & Male & $>20$ & Obtain from register databases & Obtain from register databases & 8.5 & 42663 & $\begin{array}{l}\text { Duration of follow-up, } \\
\text { calendar year at entry, age, } \\
\text { other diagnoses, emphysema, } \\
\text { chronic bronchitis }\end{array}$ & 9 \\
\hline Boffetta 2 & 2002 & Caucasian & Female & $>20$ & Obtain from register databases & Obtain from register databases & 8.5 & 50323 & $\begin{array}{l}\text { Duration of follow-up, } \\
\text { calendar year at entry, age, } \\
\text { other diagnoses, emphysema, } \\
\text { chronic bronchitis }\end{array}$ & 9 \\
\hline Talbot-Smith 1 & 2003 & Caucasian & Male & NA & Physician-diagnosed & Obtain from register databases & 19 & 124 & Age, smoking & 8 \\
\hline Talbot-Smith 2 & 2003 & Caucasian & Female & NA & Physician-diagnosed & Obtain from register databases & 19 & 155 & Age, smoking & 8 \\
\hline Vandentorren & 2003 & Mixed & Mixed & $25-59$ & Questionnaire & Obtain from register databases & 25 & 14286 & $\begin{array}{l}\text { Age, sex, educational level, } \\
\text { smoking habit, occupational } \\
\text { exposure and forced expiratory } \\
\text { volume in one second }\end{array}$ & 9 \\
\hline Littman & 2004 & Mixed & Mixed & $44-74$ & Self-reported & Obtain from register databases & 9.1 & 17698 & $\begin{array}{l}\text { Sex, exposure cohort, study } \\
\text { arm, education, body mass } \\
\text { index, years smoked and years } \\
\text { smoked squared, average } \\
\text { number of cigarettes smoked } \\
\text { per day and average number } \\
\text { of cigarettes smoked per day } \\
\text { squared, and all other lung } \\
\text { diseases, and stratified by } \\
\text { smoking status }\end{array}$ & 9 \\
\hline Turner & 2005 & Mixed & Mixed & $>30$ & Self-reported & Obtain from register databases & 19 & 26097 & $\begin{array}{l}\text { Age, gender, race, smoking, } \\
\text { education, marital status, } \\
\text { body mass index, occupational } \\
\text { exposures, beer, wine, and } \\
\text { liquor consumption, chronic } \\
\text { bronchitis, emphysema, } \\
\text { tuberculosis, intakes of } \\
\text { vegetables, fruit, fiber, and fat, } \\
\text { and passive smoking }\end{array}$ & 9 \\
\hline Brown & 2006 & Mixed & Mixed & $50-89$ & Self-reported & Self-reported & 9 & 8896 & $\begin{array}{l}\text { Age, smoking, } \\
\text { sociodemographics }\end{array}$ & 8 \\
\hline Gonzalez-Perez & 2006 & Mixed & Mixed & $20-79$ & Self-reported & Mailed questionnaires & 7 & 18792 & $\begin{array}{l}\text { Age, sex, calendar year, } \\
\text { body mass index, alcohol } \\
\text { intake, smoking status, prior } \\
\text { comorbidities, health services } \\
\text { utilization, use of aspirin, and } \\
\text { paracetamol }\end{array}$ & 8 \\
\hline $\mathrm{Ji}$ & 2009 & Mixed & Mixed & NA & Obtain from register databases & Obtain from register databases & 40 & 140425 & No & 7 \\
\hline Colak & 2015 & Mixed & Mixed & 56 & Self-reported & Obtain from register databases & 9.4 & 94097 & $\begin{array}{l}\text { Age, sex, body mass index, } \\
\text { familial pre-disposition for } \\
\text { asthma, allergy, childhood } \\
\text { asthma, hay fever, or eczema, } \\
\text { use of asthma medication, } \\
\text { occupational exposure to dust } \\
\text { and/or fumes, daily exposure } \\
\text { to passive smoking, physical } \\
\text { activity in leisure-time, } \\
\text { education, annual household } \\
\text { income, and cumulative } \\
\text { tobacco consumption }\end{array}$ & 8 \\
\hline Huang 1 & 2015 & Asian & Male & $>20$ & Obtain from register databases & Obtain from register databases & 4 & 8002536 & $\begin{array}{l}\text { Lung diseases, low } \\
\text { income, age, comorbidities, } \\
\text { urbanization and geographic } \\
\text { area }\end{array}$ & 9 \\
\hline
\end{tabular}




\begin{tabular}{|c|c|c|c|c|c|c|c|c|c|c|}
\hline Huang 2 & 2015 & Asian & Female & $>20$ & Obtain from register databases & Obtain from register databases & 4 & 7216488 & $\begin{array}{l}\text { Lung diseases, low } \\
\text { income, age, comorbidities, } \\
\text { urbanization and geographic } \\
\text { area }\end{array}$ & 9 \\
\hline Fan & 2016 & Asian & Mixed & $40-9$ & Physician-diagnosed & $\begin{array}{l}\text { Chest radiography, physician- } \\
\text { diagnosed, obtain from register } \\
\text { databases }\end{array}$ & 9 & 9295 & $\begin{array}{l}\text { Age, sex, education, smoking, } \\
\text { arsenic level, radon level, prior } \\
\text { comorbidities }\end{array}$ & 8 \\
\hline Pirie & 2016 & Mixed & Female & 56 & Questionnaire & Obtain from register databases & 14 & 634039 & $\begin{array}{l}\text { Age, region, deprivation } \\
\text { quintile, height }\end{array}$ & 7 \\
\hline
\end{tabular}

follow-up, sample size, and adjustment. The quality of the studies was high.

\section{Association of asthma and risk of lung cancer}

As shown in Figure 2, asthma was significantly associated with the increased risk of lung cancer $($ odds ratio $(\mathrm{OR})=1.44 ; 95 \%$ confidence interval $(\mathrm{CI})$ $\left.1.31-1.59 ; P<0.00001 ; I^{2}=83 \%\right)$. Additionally, asthma patients without smoking also had the increased lung cancer risk $(\mathrm{OR}=1.28 ; 95 \%$ CI $1.10-1.50 ; P=0.002$; $I=0 \%)$. In the subgroup analysis of race, both Caucasians and Asians with asthma showed the same results $\left(\mathrm{OR}=1.53 ; 95 \%\right.$ CI $1.37-1.72 ; P<0.00001 ; I^{2}=56 \%$; $\mathrm{OR}=1.52 ; 95 \%$ CI $\left.1.15-2.01 ; P<0.00001 ; I^{2}=93 \%\right)$. In the stratified analysis by gender, both male and female patients with asthma showed the increased risk of lung cancer $(\mathrm{OR}=1.38 ; 95 \%$ CI $1.31-1.46 ; P<0.00001$; $I^{2}=24 \% ;$ OR $=1.68 ; 95 \%$ CI $1.45-1.95 ; P<0.00001$;
$\left.I^{2}=63 \%\right)$. However, asthma was not significantly associated with lung adenocarcinoma risk $(\mathrm{OR}=1.01$; $95 \%$ CI $\left.0.69-1.50 ; P=0.95 ; I^{2}=45 \%\right)$. In the stratified analysis by asthma definition, significant associations were found between asthma and lung cancer in self-reported subgroup $(\mathrm{OR}=1.23 ; 95 \%$ CI $1.03-1.48 ; P=0.02$; $\left.I^{2}=53 \%\right)$, questionnaire subgroup $(\mathrm{OR}=1.32 ; 95 \% \mathrm{CI}$ $\left.1.12-1.57 ; P=0.001 ; I^{2}=0 \%\right)$, and register databases subgroup $(\mathrm{OR}=1.60 ; 95 \%$ CI 1.42-1.79; $P<0.00001$; $I^{2}=91 \%$ ). However, no significant association was observed in physician-diagnosed asthma subgroup $(\mathrm{OR}=1.26$; 95\% CI 0.96-1.65; $\left.P=0.10 ; I^{2}=0 \%\right)$. The results were showed in Table 2.

In the sensitive analysis, similar data were observed after sequentially excluding each study (Figure 3). Furthermore, when the studies without adjustment were excluded, the result was still statistically significant $\left(\mathrm{OR}=1.43,95 \%\right.$ CI $\left.1.28-1.60, P<0.00001 ; P^{2}=80 \%\right)$. In addition, after excluding the studies without adjusting

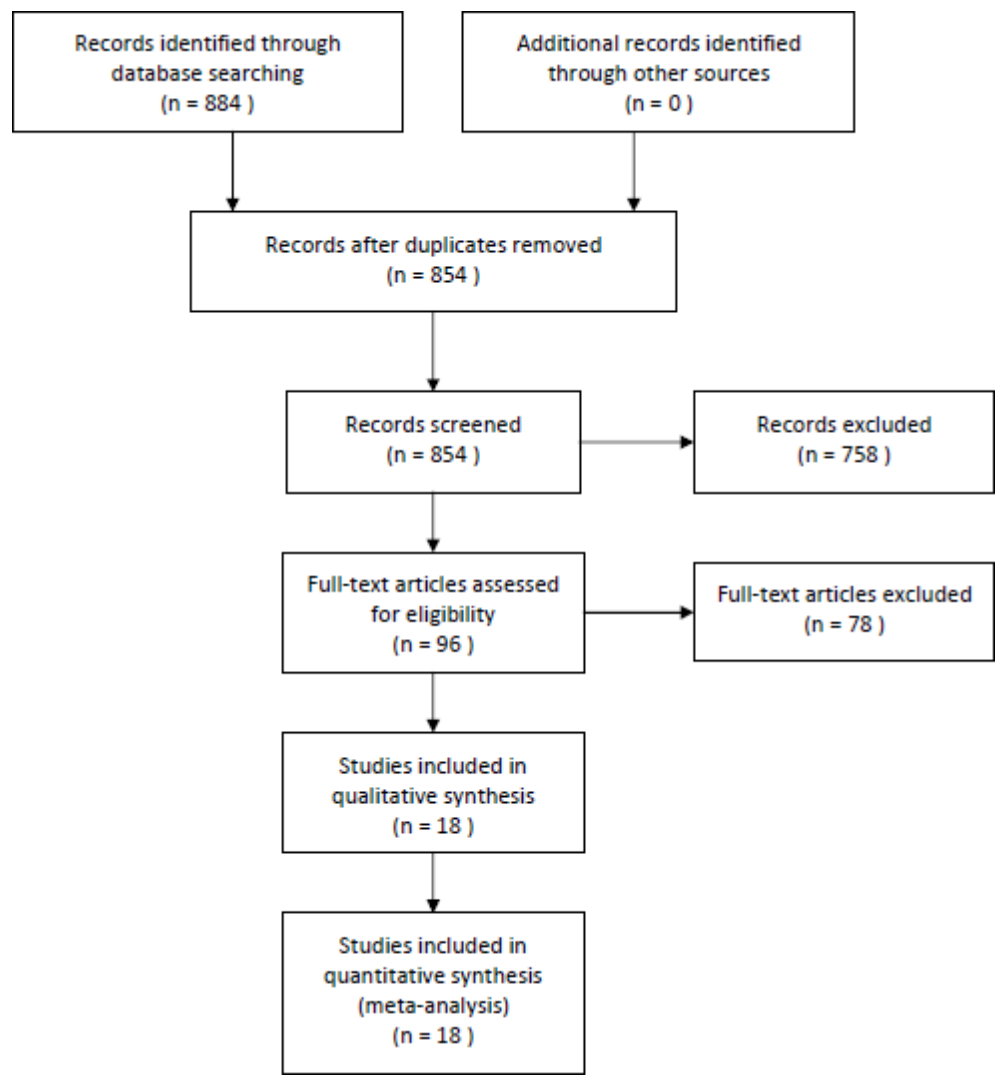

Figure 1: The selection of included studies. 
Table 2: Results of this meta-analysis

\begin{tabular}{|c|c|c|c|c|c|}
\hline & No. of study & OR $(95 \%$ CI $)$ & $\begin{array}{c}P \text { Value for } \\
\text { meta-analysis }\end{array}$ & $I^{2}(\%)$ & $\begin{array}{c}P \text { Value for } \\
\text { subgroup analysis }\end{array}$ \\
\hline Overall lung cancer risk & 23 & $1.44(1.31-1.59)$ & $<0.00001$ & 83 & \\
\hline Non-smoker & 4 & $1.28(1.10-.50)$ & 0.002 & 0 & \\
\hline \multicolumn{6}{|l|}{ Subgroup analysis } \\
\hline Race & & & & & 0.95 \\
\hline Caucasian & 9 & $1.53(1.37-1.72)$ & $<0.00001$ & 56 & \\
\hline Asian & 3 & $1.52(1.15-2.01)$ & $<0.00001$ & 93 & \\
\hline Gender & & & & & 0.02 \\
\hline Male & 6 & $1.38(1.31-1.46)$ & $<0.00001$ & 24 & \\
\hline Female & 6 & $1.68(1.45-1.95)$ & $<0.00001$ & 63 & \\
\hline Lung adenocarcinoma & 2 & $1.01(0.69-1.50)$ & 0.95 & 45 & \\
\hline Definition of asthma & & & & & 0.05 \\
\hline Self-reported & 9 & $1.23(1.03-1.48)$ & 0.02 & 53 & \\
\hline Questionnaire & 3 & $1.32(1.12-1.57)$ & 0.001 & 0 & \\
\hline Physician-diagnosed & 4 & $1.26(0.96-1.65)$ & 0.10 & 0 & \\
\hline Register databases & 7 & $1.60(1.42-1.79)$ & $<0.00001$ & 91 & \\
\hline
\end{tabular}

smoking and age, the result was not changed $(\mathrm{OR}=1.29$, $95 \%$ CI $1.12-1.48, P=0.0004 ; I^{2}=27 \%$ ). The results were showed in Table 3.

The publication bias of the included studies was assessed by the funnel plot and Egger's test. The funnel plot was symmetric (Figure 4). Egger's test showed no significant publication bias $(P=0.683)$.

\section{DISCUSSION}

This present meta-analysis investigating the relationship between asthma and lung cancer risk.
Eighteen studies with a total of 16375202 individuals were included in this meta-analysis. Prior asthma was significantly associated with lung cancer risk. In the subgroup analysis of race, both Caucasians and Asians with asthma showed the same results. In the stratified analysis by gender, both male and female patients with asthma showed the increased risk of lung cancer. Smoke habit was a recognized risk factor for lung cancer. However, asthma patients without smoking also had the increased lung cancer risk. These results suggested that asthma might be an independent risk factor for lung cancer. Lung cancer is classified small cell lung cancer

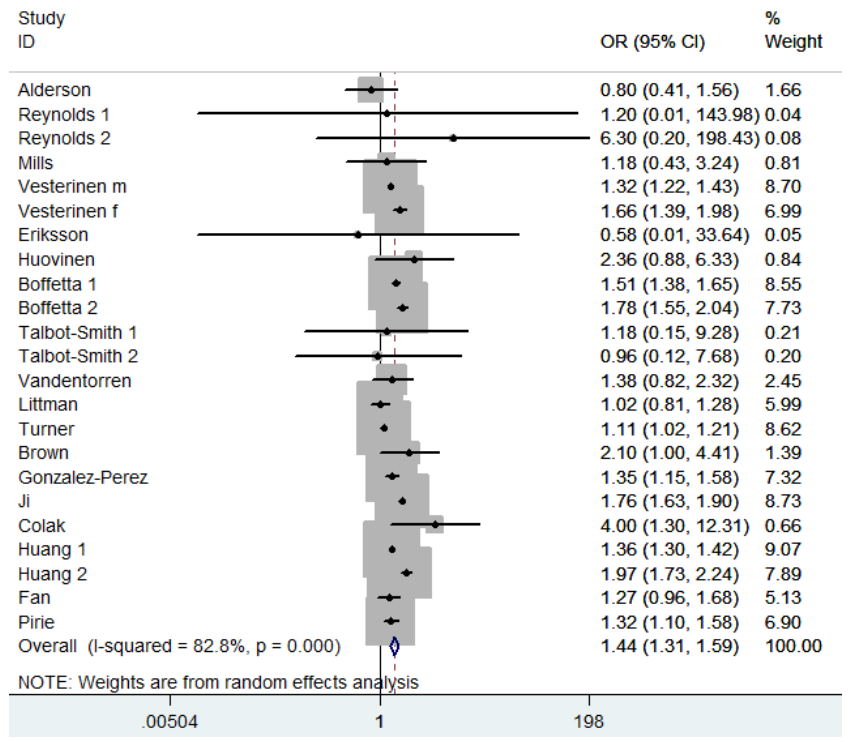

Figure 2: Meta-analysis of the association between asthma and lung cancer. 
Table 3: Results of sensitivity analysis

\begin{tabular}{lcccc}
\hline & No. of study & OR (95\% CI) & $\boldsymbol{P}$ Value & $\boldsymbol{I}^{\mathbf{2}(\%)}$ \\
\hline Studies with adjustment & 18 & $1.43(1.28-1.60)$ & $<0.00001$ & 80 \\
Adjustment with smoking and age & 12 & $1.29(1.12-1.48)$ & 0.0004 & 27 \\
\hline
\end{tabular}

and adenocarcinoma, squamous cell carcinoma, and large cell carcinoma [23]. Asthma was not significantly associated with lung adenocarcinoma risk in this metaanalysis. Future studies should be performed to assess the association between asthma and other pathological types of lung cancer. In the stratified analysis by asthma definition, significant associations were found in selfreported subgroup, questionnaire subgroup, and register databases subgroup. However, no significant association was observed in physician-diagnosed asthma subgroup. Only four studies were included in this subgroup. A positive association could therefore not be ruled out, because studies with small sample sizes may have had insufficient statistical power to detect any slight effect. To determine the stability of the result, we did sensitivity analysis. Removal of each study did not change the result,

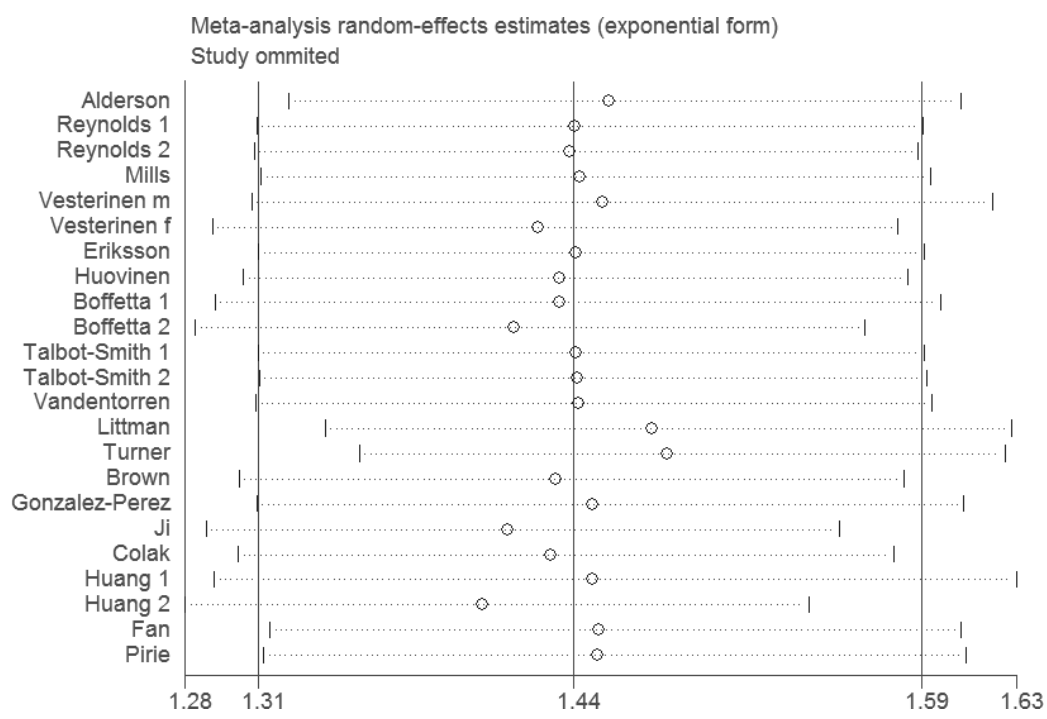

Figure 3: Sensitivity analysis of the association between asthma and lung cancer.

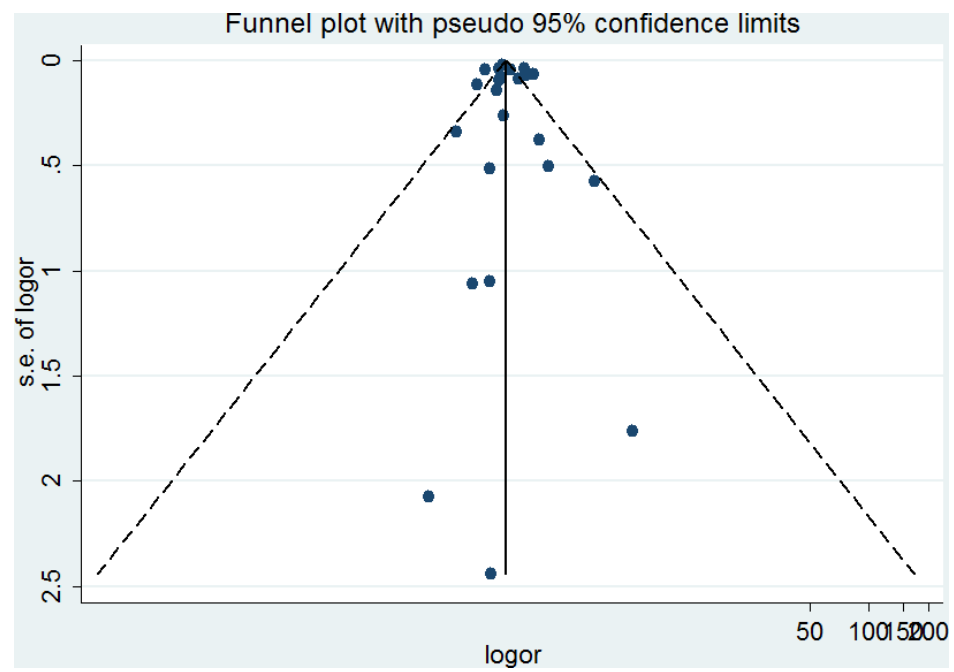

Figure 4: Funnel plot of the association between asthma and lung cancer. 
suggesting the reliability of our result. The adjusted ORs could be used to overcome some of the confounding within the observational studies. Thus, we did sensitivity analysis by excluding the studies without adjustment. The result was still statistically significant.

Asthma is a disease of chronic airway inflammation characterized by recurrent episodes of wheezing, dyspnea, chest tightness, and cough. Inflammatory cell types, such as T and B lymphocytes, mast cells, eosinophils, basophils, neutrophils and dendritic cells, as well as structural cell types including epithelial and mesenchymal cells involved in airway inflammation [24]. Inflammation also plays a pivotal role in the pathogenesis of lung cancer. Ballaz and Mulshine indicated that chronic inflammation contributes to the process of lung carcinogenesis [25]. Azad et al. suggested that chronic inflammation-induced production of reactive oxygen/nitrogen species in the lung may predispose individuals to lung cancer [26].

This meta-analysis was stable and reliable. First, sensitivity analyses revealed that the results were robust. Second, no significant publication bias was found in this meta-analysis. Third, the sample size of this meta-analysis was large enough. Several limitations should be noted. First, other races, such as African, were not included. Second, heterogeneity was high in this meta-analysis. Third, subgroup analysis based on study level variables could be due to the potential for ecological fallacy. Therefore, more studies are required to confirm the results of this meta-analysis.

In conclusion, this meta-analysis suggested that asthma might be significantly associated with lung cancer risk.

\section{MATERIALS AND METHODS}

\section{Publication search}

Two authors (YLQ and JL) searched Pubmed, Embase, Chinese National Knowledge Infrastructure (CNKI) and Wanfang databases (www.wanfangdata. com.cn). We also checked American Society of Clinical Oncology (ASCO) meeting abstracts to find grey literature (http://meetinglibrary.asco.org/abstracts). Last search was updated in 10 Nov, 2016. We searched the bibliographies of identified studies and narrative reviews for additional citations. No language and time restriction were imposed in this meta-analysis. The detailed search strategy is showed in the Supplementary Material.

\section{Study selection}

Two authors (YLQ and JL) searched the titles and abstracts obtained from the initial electronic search for potentially relevant studies for full review. Two authors (YLQ and LXZ) then assessed the full text of the retrieved studies to determine whether the study met the inclusion criteria. Studies included in this meta-analysis should meet the following criteria: (1) study design: prospective cohort study, cross-sectional study, and longitudinal study; (2) population: individuals without lung cancer; (3) exposure: asthma or wheeze; (4) comparison: individuals without asthma or wheeze; (5) outcome: relative risk (RR), hazard ratio (HR), or OR with corresponding 95\% CI of lung cancer risk in overall population and in non-smokers. If serial studies of the same population from the same group were reported, the largest study was included. Reviews, meta-analyses, letters, and editorial articles were all excluded. We resolved disagreement by consensus.

\section{Data extraction and qualitative assessment}

Two investigators (YLQ and JL) extracted the data independently. The following data were collected from each study: first author's name, year of publication, ethnicity, gender, age, asthma definition, lung cancer definition, duration of follow-up, sample size, and adjustment. The Newcastle-Ottawa Scale (NOS) was used to assess the quality of included studies.

\section{Statistical analysis}

ORs with 95\% CIs were used to calculate the strength of the association between asthma and lung cancer risk. Random effects model was used in this meta-analysis. Heterogeneity among studies was examined with $I^{2}$ statistic and Q statistic. Subgroup analysis was carried out by smoke status, ethnicity, gender, subtype of lung cancer, and definition of asthma. Relative influence of each study on the pooled estimate was assessed by omitting one study at a time for sensitivity analysis. Sensitivity analysis was also performed by excluding studies without adjustment, studies without adjustment of age and smoking. Funnel plot and Begg's test were employed to evaluate publication bias. All statistical tests were performed using the STATA 11.0 software (Stata Corporation, College Station, TX). A $P$ value $<0.05$ was considered statistically significant, except for tests of heterogeneity where a level of 0.10 was used. All tests were two-sided.

\section{ACKNOWLEDGMENTS AND FUNDING}

This work is supported by The army youth development program in medical technology (16QNP014).

\section{CONFLICTS OF INTEREST}

The authors declare that they have no conflicts of interest.

\section{REFERENCES}

1. Hecht SS. Tobacco smoke carcinogens and lung cancer. J Natl Cancer Inst. 1999; 91:1194-210. 
2. Sun S, Schiller JH, Gazdar AF. Lung cancer in never smokers - a different disease. Nat Rev Cancer. 2007; 7:778-90.

3. Koppelman GH, Stine OC, Xu J, Howard TD, Zheng SL, Kauffman HF, Bleecker ER, Meyers DA, Postma DS. Genome-wide search for atopy susceptibility genes in Dutch families with asthma. J Allergy Clin Immunol. 2002; 109:498-506.

4. Coussens LM, Werb Z. Inflammation and cancer. Nature. 2002; 420:860-7.

5. Alderson M. Mortality from malignant disease in patients with asthma. Lancet. 1974;2:1475-7.

6. Reynolds P, Kaplan GA. Asthma and cancer. Am J Epidemiol. 1987; 125:539-40.

7. Mills PK, Beeson WL, Fraser GE, Phillips RL. Allergy and cancer: organ site-specific results from the Adventist Health Study. Am J Epidemiol. 1992; 136:287-95.

8. Vesterinen E, Pukkala E, Timonen T, Aromaa A. Cancer incidence among 78,000 asthmatic patients. Int J Epidemiol. $1993 ; 22: 976-82$.

9. Eriksson NE, Holmén A, Högstedt B, Mikoczy Z, Hagmar L. A prospective study of cancer incidence in a cohort examined for allergy. Allergy. 1995; 50:718-22.

10. Huovinen E, Kaprio J, Vesterinen E, Koskenvuo M. Mortality of adults with asthma: a prospective cohort study. Thorax. 1997; 52:49-54.

11. Boffetta P, Ye W, Boman G, Nyrén. Lung cancer risk in a population-based cohort of patients hospitalized for asthma in Sweden. Eur Respir J. 2002; 19:127-33.

12. Talbot-Smith A, Fritschi L, Divitini ML, Mallon DF, Knuiman MW. Allergy, atopy, and cancer: a prospective study of the 1981 Busselton cohort. Am J Epidemiol. 2003; 157:606-12.

13. Vandentorren S, Baldi I, Annesi Maesano I, Charpin D, Neukirch F, Filleul L, Cantagrel A, Tessier JF. Long-term mortality among adults with or without asthma in the PAARC study. Eur Respir J. 2003; 21:462-7.

14. Littman AJ, Thornquist MD, White E, Jackson LA, Goodman GE, Vaughan TL. Prior lung disease and risk of lung cancer in a large prospective study. Cancer Causes Control. 2004; 15:819-27.

15. Turner MC, Chen Y, Krewski D, Ghadirian P, Thun MJ, Calle EE. Cancer mortality among US men and women with asthma and hay fever. Am J Epidemiol. 2005; 162:212-21.
16. Brown DW, Young KE, Anda RF, Felitti VJ, Giles WH. Re: asthma and the risk of lung cancer. findings from the Adverse Childhood Experiences (ACE). Cancer Causes Control. 2006; 17:349-50.

17. González-Pérez A, Fernández-Vidaurre C, Rueda A, Rivero E, García Rodríguez LA. Cancer incidence in a general population of asthma patients. Pharmacoepidemiol Drug Saf. 2006; 15:131-8.

18. Ji J, Shu X, Li X, Sundquist K, Sundquist J, Hemminki K. Cancer risk in hospitalised asthma patients. Br J Cancer. 2009; 100:829-33.

19. Çolak Y, Afzal S, Nordestgaard BG, Lange P. Characteristics and Prognosis of Never-Smokers and Smokers with Asthma in the Copenhagen General Population Study. A Prospective Cohort Study. Am J Respir Crit Care Med. 2015; 192:172-81.

20. Huang JY, Jian ZH, Nfor ON, Ku WY, Ko PC, Lung CC, Ho CC, Pan HH, Huang CY, Liang YC, Liaw YP. The effects of pulmonary diseases on histologic types of lung cancer in both sexes: a population-based study in Taiwan. BMC Cancer. 2015; 15:834.

21. Fan Y, Jiang $\mathrm{Y}, \mathrm{Hu} \mathrm{P}$, Chang R, Yao S, Wang B, Li X, Zhou Q, Qiao Y. Modification of association between prior lung disease and lung cancer by inhaled arsenic: A prospective occupational-based cohort study in Yunnan, China. J Expo Sci Environ Epidemiol. 2016; 26:464-70.

22. Pirie K, Peto R, Green J, Reeves GK, Beral V; Million Women Study Collaborators. Lung cancer in never smokers in the UK Million Women Study. Int J Cancer. 2016; 139:347-54.

23. Travis WD. Pathology of lung cancer. Clin Chest Med. 2011; 32:669-92.

24. Pelaia G, Vatrella A, Maselli R. The potential of biologics for the treatment of asthma. Nat Rev Drug Discov. 2012; 11:958-72.

25. Ballaz S, Mulshine JL. The potential contributions of chronic inflammation to lung carcinogenesis. Clin Lung Cancer. 2003; 5:46-62.

26. Azad N, Rojanasakul Y, Vallyathan V. Inflammation and lung cancer: roles of reactive oxygen/nitrogen species. J Toxicol Environ Health B Crit Rev. 2008; 11:1-15. 